\title{
DEGRADATION OXIRANE RING KINETICS OF EPOXIDIZED PALM KERNEL OIL- BASED CRUDE OLEIC ACID
}

\author{
Mohd J umain Jalil1, * , Siti Khatijah Jamaludin¹, \\ Ahmad Rafizan Mohammad Daud ${ }^{1}$
}

https://doi.org/10.23939/chcht12.03.296

\begin{abstract}
The epoxidation of oleic acid was carried out by using in situ generated performic acid $(\mathrm{HCOOOH})$ to produce epoxidized oleic acid. Performic acid was formed by mixing formic acid (as oxygen carrier) and hydrogen peroxide (as oxygen donor). The epoxide ring is very reactive, especially in the presence of acidic condition making the epoxide a suitable intermediate for synthesis of other chemicals. The most likely side reaction that occurred in the in situ epoxidation is the reaction of oxirane ring with formic acid, which led to formation of diol and $a$-glycol as side products. Oxirane cleavage of the epoxide was studied and suggests first order in oxirane concentration and second order with respect to formic acid.
\end{abstract}

Keywords: oleic acid, epoxidation, degradation, palm oil.

\section{Introduction}

Studies pertaining to epoxidation of fatty acids have garnered much interest in the recent years due to the rising demand for eco-friendly epoxides derived from vegetable oils. Epoxide is an important chemical precursor for the production of alcohols, glycols and polymers like polyesters and epoxy resin.

Vegetable oils can be epoxidized, as they mainly consist of unsaturated triglycerides. Produced epoxides are valuable as intermediates for resin, as paint and coating components, and as the plasticizers and stabilizers for poly(vinylchloride). Palm kernel oil- based crude oleic acid was selected as a raw materials since oleic its can categorized as a low value co-product during the production of crude lauric and myristic acid. The epoxidation is carried out by reacting the double bonds of the oil with peroxyacid (generally peroxyacetic or peroxyformic acid) generated in situ by reacting concentrated hydrogen peroxide with formic acid in the

\footnotetext{
${ }^{1}$ Universiti Teknologi Mara, Cawangan Pulau Pinang, Jalan Permatang Pauh,

13500 Permatang Pauh, Pulau Pinang, Malaysia

* mjumain0686@ppinang.uitm.edu.my

(C) Jalil M., Jamaludin S., Daud A., 2018
}

presence of a mineral acid as catalyst. A small amount of sulfuric acid is necessary to catalyze the oxidation of the formic acid to the corresponding performic acid.

Epoxy ring-opening also known as epoxide cleavage or epoxide ring degradation occurs in the epoxidation of vegetable oils. It is imperative to minimize the process losses via ring-opening in order to achieve good yields and high peroxide values of the epoxidized vegetable oils. The oxirane ring will react with formic acid during in situ epoxidation, resulting formation of side reaction [1].

$$
\begin{aligned}
& \mathrm{R}_{1}-\mathrm{HC}-\mathrm{O}-\mathrm{CH}-\mathrm{R}_{2(l)}+\mathrm{CHOOH}_{(l)} \rightarrow \\
& \rightarrow \mathrm{R}_{1}-\mathrm{CH}(\mathrm{OH})-\mathrm{CH}(\mathrm{OOCH})-\mathrm{R}_{2(l)}
\end{aligned}
$$

The oxirane rings are highly reactive and susceptible to opening, especially in the presence of acidic conditions due to the fact that the epoxides act as intermediates for synthesis of other chemicals. The cleavage of oxirane rings is most pronounced in the presence of sulphuric acid, followed by formic acid, acetic acid and propionic acid. Acidic conditions promote ringopening by protonation of the epoxide oxygen atoms, which consequently react with different types of nucleophilic reagents via back side attack in order to give anti-orientation type products [1]. Since the epoxidized oil is in cis-configuration, its ring-opening products are in trans-configuration.

\section{Experimental}

\section{1. $M$ aterials}

Crude oleic acid was purchased from Chung Chemical Sdn. Bhd. Aqueous hydrogen peroxide (30\%), formic acid, sulfuric acid, and phosphorus acid were all purchased from Merck Sdn. Bhd without pretreatment.

\subsection{M ethods}

Oleic acid, formic acid and sulfuric acid were added into a reactor and temperature was raised until stabilized. The hydrogen peroxide was then added dropwise at room temperature under continuous stirring. 
The epoxidation was carried out in a reactor with the capacity of 21 under agitation constant speed of $300 \mathrm{rpm}$. Crude oleic acid, formic acid and sulfuric acid as a catalyst were added simultaneously into the reactor. The mixture was stirred continuously at fixed speed and was gradually heated to required temperature and kept at a constant temperature for the selected reaction time. The hydrogen peroxide was then added drop by drop at room temperature under constant stirring. Samples were analyzed by withdrawing approximately $5 \mathrm{ml}$ of reaction mixture every $5 \mathrm{~min}$. The reactor was directly connected to the control panel to control the temperature and agitation speed.

\section{Results and Discussion}

\subsection{Effect of Oxygen Carrier on the Reaction Rate}

Two types of oxygen carrier (peracid) investigated were in situ peracetic and performic acids. The in situ peracids were formed following Eqs. (2) and (3) for performic and peracetic acids, respectively [2].

$\mathrm{CHOOH}_{(l)}+\mathrm{H}_{2} \mathrm{O}_{2(l)} \leftrightarrow \mathrm{CH}_{2} \mathrm{O}_{3(l)}+\mathrm{H}_{2} \mathrm{O}_{(l)}$

$\mathrm{CH}_{3} \mathrm{COOH}_{(l)}+\mathrm{H}_{2} \mathrm{O}_{2(l)} \leftrightarrow \mathrm{CH}_{4} \mathrm{CO}_{4(l)}+\mathrm{H}_{2} \mathrm{O}_{(l)}$

Their influences on the epoxidation of oleic acid are shown in Fig. 1. It shall be noted that epoxidation can be carried out using either formic acid or acetic acid [3]. Formic acid (methanoic acid) is the simplest form of carboxylic acid which occurs naturally and is an important chemical intermediate. It can be seen from Fig. 1 that the maximum yield of epoxide was achieved when formic acid was used as the oxygen carrier compared to acetic acid. It is likely that the high epoxide yield obtained was due to the immediate reaction between the performic acid formed with the $\mathrm{C}=\mathrm{C}$ double bonds in the oleic acid chain as well as minimization of oxirane ring degradation. According to G. Wu et al. [4] formic acid has the ability to minimize oxirane ring-opening by preventing the deprotonation of performic acid. Furthermore, it can be observed that the time taken to produce maximum yield of epoxides was reduced when formic acid was used as the oxygen carrier. Nevertheless, should the in situ performic acid concentration become too high, it will contribute to a strong acidic condition, which causes severe loss of epoxide by ring opening route. In this case, use of inert solvents such as heptanes and toluene was suggested by E. Santacesaria et al. [5] and the addition of acidneutralizing compounds was recommended during the epoxidation process in order to maintain the $\mathrm{pH}$ value of 3-6 [6]. Selection of oxygen carrier does not only affect the rate of conversion to oxirane, but also the stability of oxirane produced [2].

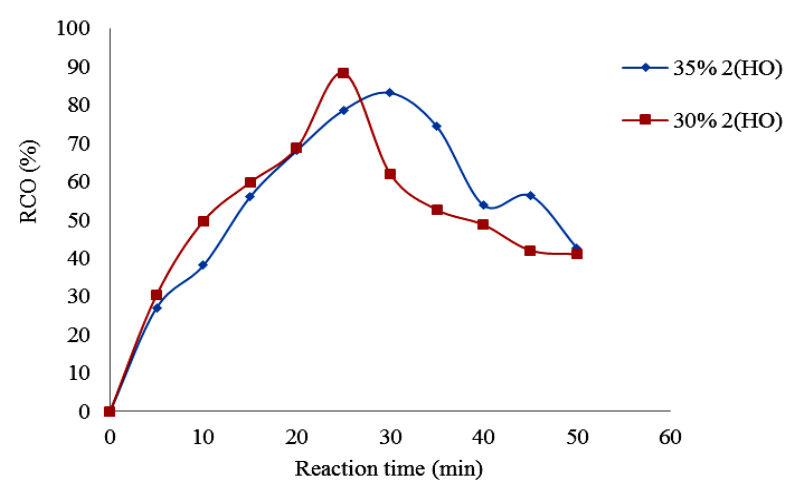

Fig. 1. Effect of oxygen carrier on the percentage of relative conversion to oxirane

\subsection{Kinetic of Oxirane-Ring Opening}

It is known that the oxirane rings are very reactive and susceptible to opening, particularly in the presence of acidic conditions. The oxirane cleavage is a complex process. According to B. Lin et al. [7], it is very likely that the oxirane rings will react with formic acid during in situ epoxidation, resulting in the formation of side products. Hence, this reaction may be regarded as a reasonable representation of the whole side reaction in the absence of a detailed cleavage product analysis. The general rate equation of the oxirane ring process by the action of formic acid is given by Eq. (4):

$$
\frac{-d C_{E p O A}}{d t}=k^{\prime} C_{E p O A}^{a} C_{F A}^{b}
$$

where $\frac{-d C_{E p O A}}{d t}$ is the rate of oxirane-ring opening and $k$, is the rate constant. $C_{E P O A}^{a}$ and $C_{F A}^{b}$ represent the molar concentration of the epoxide component and formic acid, respectively; $a$ and $b$ represent the reaction order of the epoxide component and formic acid, respectively.

If the formic acid is used in excessive amounts compared to the moles of epoxide, the formic acid can be considered as a pseudo zero order reaction. The rate equation is therefore given by Eq. (5):

$$
\frac{-d C_{E p O A}}{d t}=k_{p}{ }^{\prime} C_{E p O A}^{a}
$$

where $k_{p}{ }^{\prime}=k^{\prime} C_{F A}^{b}$.

The reaction order with respect to the epoxide is derived from measurements at 298, 318, 328 and $338 \mathrm{~K}$ with the epoxide:formic acid molar ratio of $1: 10$. The values of $\ln \left([E p O A]_{0} /[E p O A]\right)$ versus reaction time of the oxirane ring-opening of epoxidized oleic acid were plotted for each reaction temperature as shown in Fig. 2. The plots suggested that the reaction mechanism is a pseudofirst-order reaction with respect to the concentration of 
epoxide. The results agree well with those reported in Ref. $[3,8]$, where the cleavage of oxirane rings by formic acid in epoxidized vegetable oils was studied.

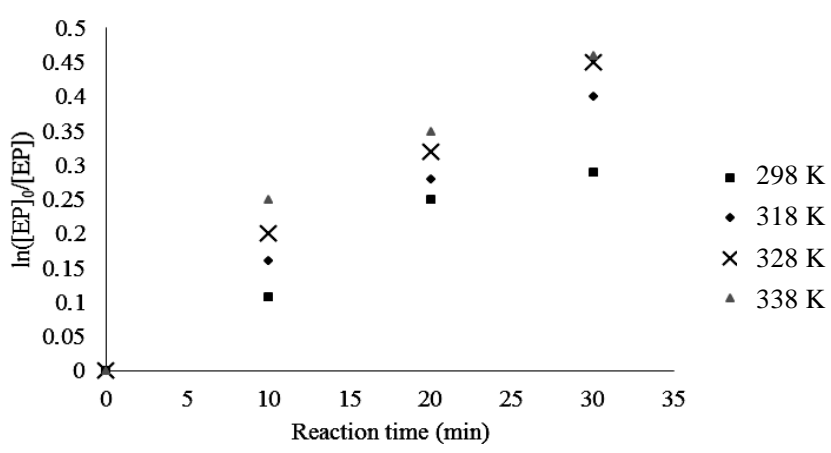

Fig. 2. Effect of reaction temperature on the oxirane ring-opening

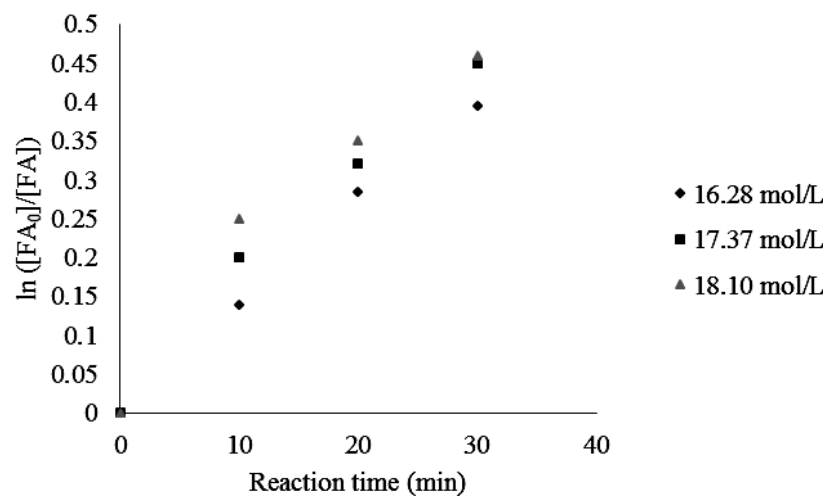

Fig. 3. Determination of rate constants $k_{p}{ }^{\prime}$

at various concentrations of formic acid

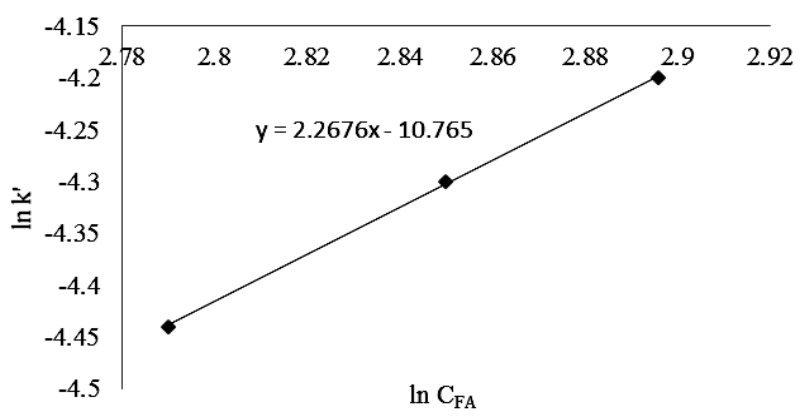

Fig. 4. Order of reaction regarding the initial concentration of formic acid

The $k_{p}{ }^{\prime}$ value at $318 \mathrm{~K}$ was determined for three concentrations of formic acid in order to obtain the reaction order with respect to the formic acid as shown in Fig. 3. The value was found to be $1.34 \cdot 10^{-2}, 1.47 \cdot 10^{-2}$ and $1.52 \cdot 10^{-2} \mathrm{~min}^{-1}$ at formic acid concentration of 16.28 , 17.37 and $18.10 \mathrm{~mol} \cdot \mathrm{l}^{-1}$, respectively. The values obtained in this work are quite close to those obtained by A. Campanella et al. [9], who investigated the degradation of oxirane rings using solvated acetic acid. They found the value was $6.15 \cdot 10^{-3} \mathrm{~min}^{-1}$ at $333 \mathrm{~K}$.

Since $k_{p}{ }^{\prime}=k^{\prime} C_{F A}^{b}$, the rate equation can be represented in natural logarithm form as follows:

$$
\ln k_{p}{ }^{\prime}=\ln k^{\prime}+b \ln C_{F A}
$$

The reaction order with respect to formic acid was obtained from the slope of a plot $\ln k_{p}{ }^{\prime}$ versus $\ln C_{F A}$ as presented in Fig. 4. The determined slope was $2.11 \cdot 10^{-5} 1 \cdot \mathrm{mol}^{-1} \cdot \mathrm{min}^{-1}$. Therefore, the oxirane ring cleavage reaction is second order with respect to the formic acid concentration and first order with respect to concentration of epoxide as shown in Eq. (7). This result can be used to understand the effect of formic acid concentration on the net yield of epoxides by in situ epoxidation. It is worth to note that performic acid is formed from the reaction between formic acid and hydrogen peroxide and it is a reversible reaction. Hence, an increase in formic concentration will increase the equilibrium concentration of performic acid in the reaction mechanism, which in turn, increases oxirane formation at a rate which is less than that for oxirane cleavage. Thus, the use of higher concentrations of formic acid during in situ epoxidation will certainly decrease the net yield of epoxides [10]. Hence, a low mole ratio of formic acid to oleic acid should be used whenever epoxide derivatives are the desired products. In conclusion, rate equation of the oxirane ring process by the action of formic acid is given by:

$$
\frac{-d C_{E p O A}}{d t}=0.012 C_{E p O A}^{1} C_{F A}^{2}
$$

\section{Conclusions}

Epoxidized vegetable oils have gained great importance in the recent years due to being derived from renewable and sustainable resources and therefore perceived as environmental friendly. In this study, crude oleic acid derived from palm kernel oil has been epoxidized using in situ formed performic acid ( $\mathrm{HCOOOH})$ to produce epoxidized oleic acid. The result of this study shows that the oxirane ring cleavage reaction is second order with respect to the formic acid concentration and first order with respect to concentration of epoxide.

\section{Acknowledgments}

The authors would like to thank the Ministry of Education Malaysia and IRES with registration number is 600-IRMI/PTB 5/3 (016/2017). The authors also gratefully acknowledge use of services and facilities of Faculty of Chemical Engineering, Universiti Teknologi MARA, Malaysia. 


\section{References}

[1] Gunstone F.: Fatty Acid and Lipid Chemistry. Aspen Publisher Inc., Maryland 1999.

[2] Dinda S., Patwardhan A., Goud V., Pradhan N.: Bioresource Technol., 2007, 99, 3737.

[3] Gound V., Pradhan N., Dinda S., Patwardhan A.: Chem. Eng. Sci., 2007, 62, 4065. https://doi.org/10.1016/j.ces.2007.04.038.

[4] Wu G., Wang Y., Wang L. et al.: Chem. Eng. J., 2013, 215-216, 306. https://doi.org/10.1016/j.cej.2012.11.055

[5] Santacesaria E., Tesser R., Serio M. et al.: Chem. Eng. J., 2011, 173, 198. https://doi.org/10.1016/j.cej.2011.05.018

[6] Chou T.-C., Chang J.-Y.: Chem. Eng. Commun., 1986, 41, 253. https://doi.org/10.1080/00986448608911722.

[7] Lin B., Yang L., Dai H., Yi A.: J. Am. Oil Chem. Soc., 2008, 85, 113. https://doi.org/10.1007/s11746-007-1187-5

[8] Gan L., Goh S., Ooi K.: J. Am. Oil Chem. Soc., 1992, 69, 347. https://doi.org/10.1007/BF02636065

[9] Campanella A., Fontanini C., Baltanas A.: Chem. Eng. J., 2008, 144, 466. https://doi.org/10.1016/j.cej.2008.07.016

[10] Jalil J., Mohammad N., Jamaludin S. et al.: Adv. Mat. Res., 2014, 906, 125.

https://doi.org/10.4028/www.scientific.net/AMR.906.125

Received: June 08, 2017 / Revised: June 14, 2017 / Accepted: September 01, 2017

\section{КІНЕТИКА РОЗКЛАДУ \\ ОКСИРАНОВОГО КІЛЬЦЯ \\ ОЛЕЇНОВОЇ КИСЛОТИ НА ОСНОВІ ЕПОКСИДОВАНОЇ КІСТОЧКОВОЇ ПАЛЬМОВОї ОЛІї}

\begin{abstract}
Анотація. Для одержання епоксидованої олеїнової кислоти проведено ї̈ епоксидування з використанням in situ пероксимурашиної кислоти (НСОООН). Пероксимурашину кислоту одержано внаслідок змішування мурашиної кислоти (як кисневого носія) та пероксиду водню (як донора кисню). Встановлено, щуо епоксидне кільце є дуже реакиійним, особливо в присутності кислоти, щяо дає можсливість використовувати епоксид для синтезу інших сполук. Показано, щзо найбільш ймовірною побічною реакиією, яка виникає при епоксидуванні іп situ, є реакиія оксиранового кільия з мурашиною кислотою, щчо призводить до утворення побічних продуктів діола та $\alpha$ гліколю. Досліджено розклад оксирану епоксиду та встановлено, щзо реакиія є першого порядку щодо оксирану та другого порядку - щзодо мурашиної кислоти.
\end{abstract}

Ключові слова: олеїнова кислота, епоксидація, розклад, пальмова олія. 